UDC 621.577

DOI: $10.15587 / 2313-8416.2016 .74642$

\title{
USE OF GEOTHERMAL PILES COMBINED WITH PILE FOUNDATIONS
}

\section{(C) I. Kuzytskyi}

The possibility of use of geothermal piles in conditions of cold climate is considered. Full-scale experiment is conducted for using this technology in Kiev. Obtained results testify about a possibility for using the system in conditions of Ukraine, but this technology requires more detailed study and simulation of multiannual cycle of use of geothermal piles

Keywords: heat pumps, energy pile, geothermal energy, energy efficiency

В роботі розглянуто можливість використання енергетичних паль в умовах холодного клімату. Проведено натурний експеримент по використанні даної технологї̈ в м. Київ. Отримані результати показали можливість успішної експлуатації системи в умовах Украӥни, про те технологія потребує більш детального вивчення та моделювання багаторічного циклу використання енергетичних паль

Ключові слова: теплові насоси, енергетична паля, геотермальна енергія, енергоефективність

\section{Introduction}

Based on US energy statistics $40 \%$ of the annual energy consumption is spent on residential and commercial buildings. More than half of these costs fall on heating, ventilation and air conditioning [1]. A similar situation is observed in central Europe.

Given the increase in energy prices and the fight against harmful emissions of $\mathrm{CO}_{2}$, heat pumps equipment is developed rapidly. Ukraine has implemented many projects using ground heat exchanger and geothermal probes, but these schemes are possible only in the presence of a large free area near the house. Usually the most active part in the implementation of energy efficient technologies performs commercial developers in central areas of major cities. One of the main obstacles to the realization of the project is to provide buildings with heating and cooling. Often heating providing of object is impossible without reconstruction of city heat network and has substantial capital costs.

Geothermal pile can help to solve this problem. The idea of using geothermal piles is not new and was first implemented in Austria at the end of 1980, which allowed getting 25-50 W/m low-grade heat energy, depending on the soil [2]. \section{statement}

\section{Analysis of published data and problem}

Calculations and construction schemes for geoprobes and geocollectors are well described in the literature [3-5] and are widely used in everyday life among the assembly and design organizations.

Geothermal pile - is loaded bearing piles with closed loop pipe attached to the frame of the pile and used as a soil heat exchanger for heat pump systems or as a passive cooling source. The technology driving of using geothermal piles requires a complex calculation, clear universal methods of calculation not exist to date. Despite the fact that the some objects using geothermal piles today and will be design to the future, many leading universities are working on research using thermal piles [6-8], the guarantees structural strength and increase its durability.

\section{The purpose and objectives of research}

The aim of the study is to conduct a pilot experiment on the use of geothermal piles to evaluate the effectiveness of their work in central European climate.

To achieve these goals were set and solved the following problems:

- Determination of the thermal capacity of the soil by drilling test well and establishment of the geological section;

- Creation of experimental stand for realization experiment and recording received data;

- Determine the average heat flux from geothermal piles to assess the feasibility of its use;

- Determine the lower critical temperature concrete in piles under thermal load.

4. Materials and methods of research geothermal piles

Based on the assumptions [9] and in accordance with the recommendations of the normative literature [10], group of experts LLC «UNIVENTHERM» respectively project «BIP PM» «Construction of residential complex with offices, technical premises and underground parking on the street. Mechnikov 11-A in Pechersk district at Kyiv » was conducted an experiment in which drilling-hammer pile height of 20 meters was used. This pile was passed the test of strength and will not be used as a load-bearing structure of the building in the future. Soil geological section is shown in Fig. 1.

\section{1. Technology unit of geothermal piles}

1. Contours of pipes PE80 (SDR 11) DIA 32 $\mathrm{mm}$ were fixed to hard welded reinforcing cage.

2. Since the depth of $6 \mathrm{~m}$. was installed thermoresistance pair temperature sensors every $5 \mathrm{~m}$ to establish deflection temperature gradient in piles throughout its length. 5 pairs of sensors are installed.

3 . Frame of piles lowered into the well.

4. The contours of the pipeline brought out piles and filled heat carrier (ethanol solution of $25 \%$ by volume). 


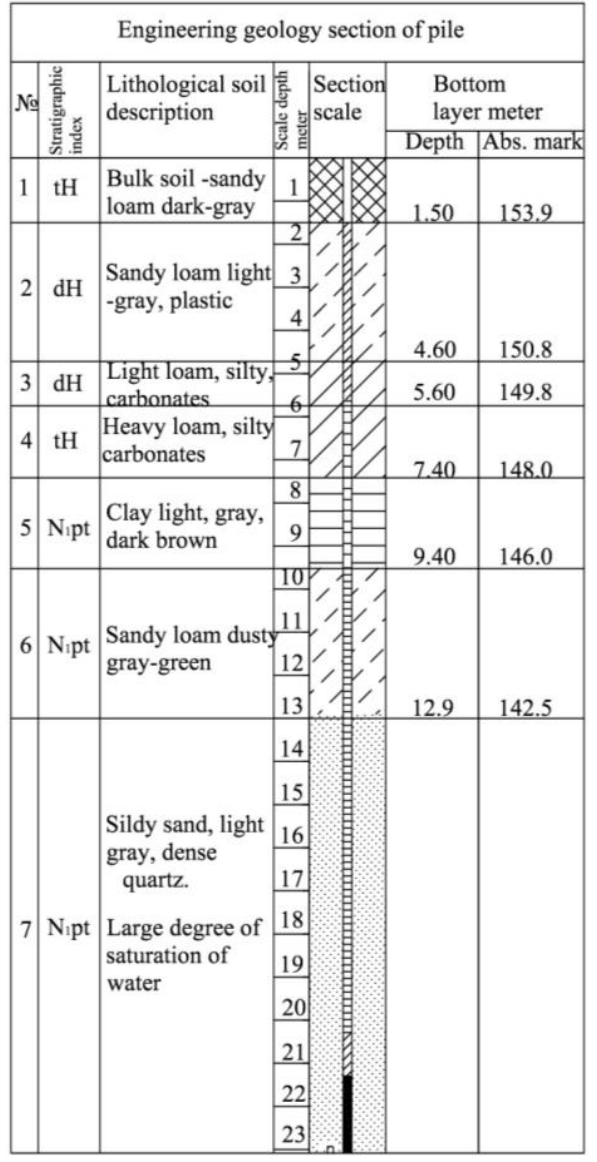

Fig. 1. Geological section of soil

5. An installation of control equipment with gauge at the end of the pipeline.
6 . Before concreting made test system integrity, pushing of 6 bar pressure.

7. Tops pipelines stretched beyond the pile to prevent damage when casting concrete piles. Pouring concrete made to complete filling of the pile. the heater.

8 . Connection - directly from the pile to

\section{2. Description of establishing stand}

Test stand was installed to perform the test, which include next monitoring equipment:

- air-heating aggregate Volcano mini, which utilizes the heat received from the contours of pipes laid to the pile;

- circulation pump Grundfos UPS 20-40 130, which provides a constant circulation of heat carrier;

- water meter VLF-R 1/2";

- radial $1 / 2$ " bimetal thermometers are installed on a return and supply pipelines;

- balancing valve Oventrop Cocon QTZ, for control heat carrier and regulate the amount of heat received from the contour of pipes, which are laid in the pile;

- shield Automatics with the panel temperature data, received from the temperature sensors in the pile;

Equipment stand directly connected to the contours of pipes laid in the pile and operates as a single system. Schematic diagram of the experimental stand is shown in Fig. 2.

The research was started 28 days after montage of the stand, the concrete gain strength was reached. During this period our team keeps tabs on pressure in pipes to avoid any damages.

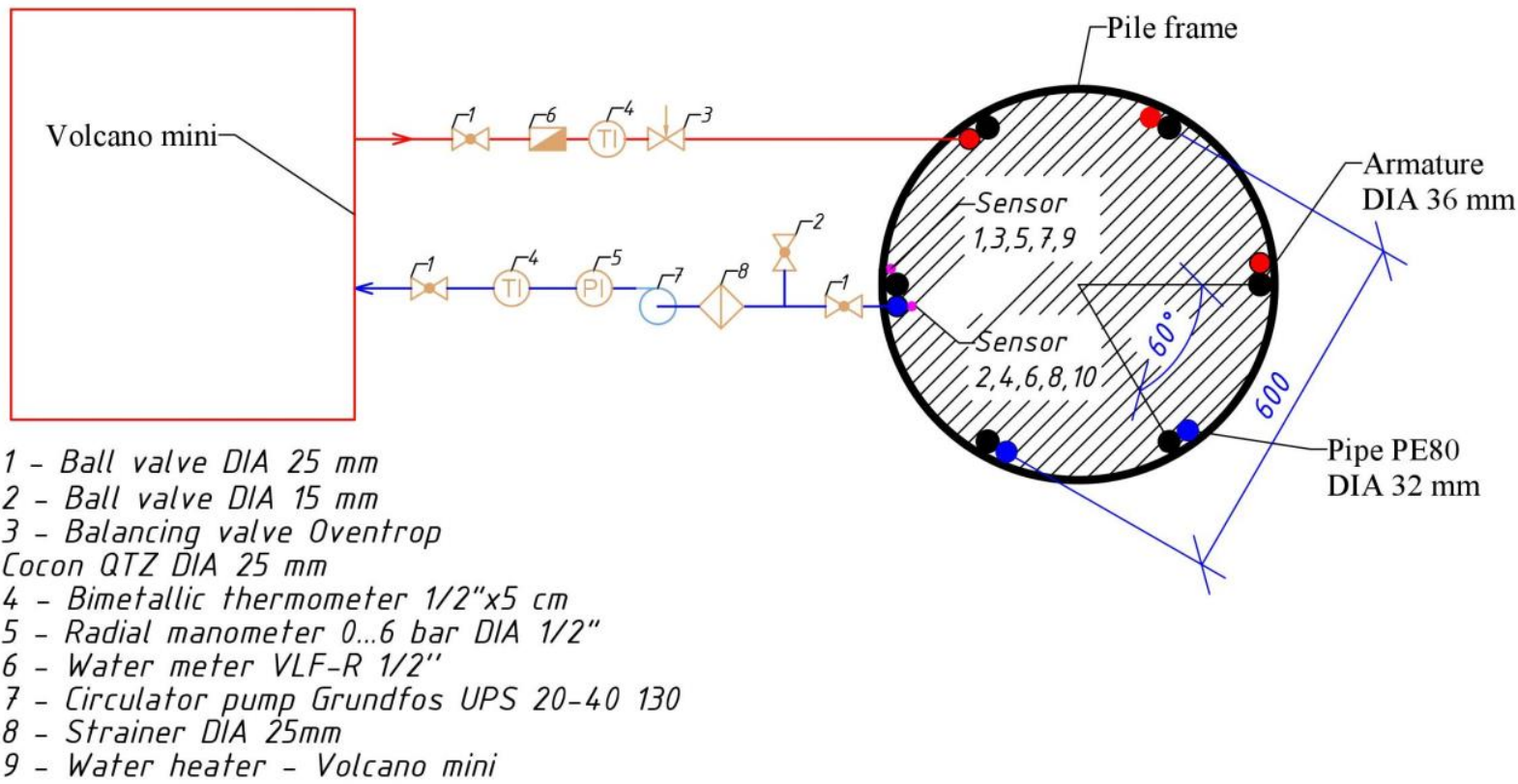

Fig. 2. Schematic diagram of experimental stand for efficiency research of geothermal piles

\section{Results of the experiment and data pro-} cessing

Work on measurements was performed from 02.09.2015 to 02.17.2015 using automation systems and temperature sensors. Investigated conditions were close to reality using all necessary parameters. Measurements are taken once a day. The length of the pile, used as a heat exchanger, $-20 \mathrm{~m}$. Table 1 data are indicators of experimental measurements of the stand. 
Table 1

Monitoring of thermal pile temperature

\begin{tabular}{|c|c|c|c|c|c|c|}
\hline Date & $\begin{array}{c}\text { Heat carrier } \\
\text { amount, } \\
\mathrm{m}^{3} / \text { hour }\end{array}$ & $\begin{array}{c}\text { Average outdoor } \\
\text { temperature T, }{ }^{\circ} \mathrm{C}\end{array}$ & $\begin{array}{c}\text { Temperature of } \\
\text { supply heat } \\
\text { carrier T1, }{ }^{\circ} \mathrm{C}\end{array}$ & $\begin{array}{c}\text { Temperature of } \\
\text { recirculation heat } \\
\text { carrier T2, }{ }^{\circ} \mathrm{C}\end{array}$ & $\begin{array}{c}\text { Sensor } \\
\text { data № 1, } \\
{ }^{\circ} \mathrm{C}\end{array}$ & $\begin{array}{c}\text { Sensor } \\
\text { data № 2, } \\
{ }^{\circ} \mathrm{C}\end{array}$ \\
\hline 02.09 .2015 & 0,36 & $-5,4$ & 12,5 & 9,5 & 11,6 & 11,7 \\
\hline 02.10 .2015 & 0,36 & $-9,1$ & 10,4 & 7,3 & 11,8 & 11,9 \\
\hline 02.11 .2015 & 0,36 & $-9,0$ & 9,1 & 6,1 & 9,8 & 9,1 \\
\hline 02.12 .2015 & 0,36 & $-2,0$ & 8,2 & 5,0 & 8,7 & 8,8 \\
\hline 02.13 .2015 & 0,36 & $-1,0$ & 7,8 & 4,8 & 8,7 & 8,7 \\
\hline 02.14 .2015 & 0,36 & $-3,0$ & 7,0 & 4,0 & 8,3 & 8,1 \\
\hline 02.15 .2015 & 0,36 & $-3,0$ & 7,0 & 3,5 & 8,1 & 7,8 \\
\hline 02.16 .2015 & 0,36 & $-6,27$ & 6,0 & 2,0 & 7,5 & 7,1 \\
\hline 02.17 .2015 & 0,36 & $-7,1$ & 6,0 & 2,0 & 7,2 & 6,7 \\
\hline
\end{tabular}

Table2

Monitoring of thermal pile temperature (continuation)

\begin{tabular}{|c|c|c|c|c|c|c|c|c|}
\hline $\begin{array}{c}\text { Sensor } \\
\text { data № 3, } \\
{ }^{\circ} \mathrm{C}\end{array}$ & $\begin{array}{c}\text { Sensor } \\
\text { data № 4, } \\
{ }^{\circ} \mathrm{C}\end{array}$ & $\begin{array}{c}\text { Sensor } \\
\text { data № 5, } \\
{ }^{\circ} \mathrm{C}\end{array}$ & $\begin{array}{c}\text { Sensor } \\
\text { data № 6, } \\
{ }^{\circ} \mathrm{C}\end{array}$ & $\begin{array}{c}\text { Sensor } \\
\text { data № 7, } \\
{ }^{\circ} \mathrm{C}\end{array}$ & $\begin{array}{c}\text { Sensor } \\
\text { data № 8, } \\
{ }^{\circ} \mathrm{C}\end{array}$ & $\begin{array}{c}\text { Sensor } \\
\text { data № 9, } \\
{ }^{\circ} \mathrm{C}\end{array}$ & $\begin{array}{c}\text { Sensor } \\
\text { data № 10, } \\
10\end{array}$ & $\begin{array}{c}\text { Q, } \\
\mathrm{kW}\end{array}$ \\
\hline 14,1 & 11,3 & 14,5 & 9,8 & 13,3 & 12,2 & 10,5 & 9,4 & 1,05 \\
\hline 14,2 & 12,2 & 14,7 & 9,5 & 13,9 & 12,2 & 11,9 & 10,2 & 1,09 \\
\hline 11 & 9,2 & 10,7 & 6,8 & 10,5 & 8,9 & 8,7 & 7,1 & 1,05 \\
\hline 10,5 & 8,9 & 10,3 & 6,3 & 10,1 & 8,6 & 8,5 & 7,0 & 1,12 \\
\hline 10,3 & 8,7 & 10,1 & 6,2 & 9,9 & 8,4 & 8,3 & 6,8 & 1,05 \\
\hline 9,9 & 8,1 & 9,6 & 5,5 & 9,4 & 7,7 & 7,6 & 5,9 & 1,05 \\
\hline 9,4 & 7,8 & 9,1 & 5,1 & 9,0 & 7,3 & 7,4 & 5,7 & 1,23 \\
\hline 8,8 & 7,0 & 8,4 & 4,7 & 8,4 & 6,5 & 6,6 & 4,7 & 1,40 \\
\hline 8,2 & 6,6 & 7,7 & 3,6 & 7,8 & 6,1 & 6,2 & 4,5 & 1,40 \\
\hline
\end{tabular}

The amount of heat is obtained from a pile of pipes paths was calculated by the formula (1).

$$
\frac{d Q}{d \tau}=\frac{\mathrm{c} \cdot \mathrm{m} \cdot\left(\mathrm{dT}_{1}-\mathrm{dT}_{2}\right)}{d \tau}=\frac{\mathrm{c} \cdot \rho \cdot \mathrm{V} \cdot\left(\mathrm{dT}_{1}-\mathrm{dT}_{2}\right)}{d \tau},
$$

where $\mathrm{Q}$ - heat $(\mathrm{J}), \mathrm{c}$ - heat capacity of ethanol solution $\left(\mathrm{J} /\left(\mathrm{kg} \cdot{ }^{\circ} \mathrm{C}\right)\right), \mathrm{T}_{1}, \mathrm{~T}_{2}-$ heat carrier temperature supply and return $\left({ }^{\circ} \mathrm{C}\right), \rho-$ ethanol solution density $\left(\mathrm{kg} / \mathrm{m}^{3}\right), \mathrm{V}-$ ethanol solution volume $\left(\mathrm{m}^{3}\right)$.

$$
\begin{aligned}
& Q_{\text {middle }}= \\
& =(3,75 \cdot 0,36 \cdot 945 \cdot(8,2-4,9) / 3,6) / 1000=1,17 \mathrm{~kW},
\end{aligned}
$$

The average heat flux from 1 meter of piles:

$$
q_{\text {middle }}=Q_{\text {middle }} / L=1,17 / 20 \cdot 1000=58,5 \mathrm{~W} / \mathrm{m},
$$

where $\mathrm{L}$ - length of pile (m).

Compliance with the standard [10], the minimum temperature of the return heat carrier can be $2{ }^{\circ} \mathrm{C}$ to avoid freezing of the soil, so the research was focused on this mark. Thus, the minimum external temperature of the piles, for the entire period of the experiment, was $3.6{ }^{\circ} \mathrm{C}$. Therefore, we can conclude that the minimum heat carrier temperature will not affect the strength characteristics of the pile, as it is within acceptable norms.

It is note that when we will use the heat pump, the temperature of supply and return heat carrier will remain stable during the heating season and will make an average of $11 / 8^{\circ} \mathrm{C}$. As the heat carrier will not cooling by the outside air and specified by settings of the heat pump, heat flow will be stable.

\section{Discussion of research results effectiveness of using thermal piles}

After the study of thermal efficiency of the piles in Ukraine it can be said that this technology is appropriate for use and fits well with cold climate. The amount of heat obtained from contour of pipes per hour ranged from 1.05 to $1.4 \mathrm{~kW}$. According calculated specific amount of thermal energy per meter was about $58,5 \mathrm{~W} / \mathrm{m}$, which is a confirmation of the theoretical calculations. It should also be noted that geothermal pile can be used as a passive or active cooling source not in the heating season, which considerably increases the potential for their use.

\section{Conclusions}

It is apparently require a detailed study of the processes of heat exchange between piles and surrounding soil to determine the optimal parameters of soil heat exchanger. In addition, it is noted that the temperature inside the pile unchanged throughout the experiment, indicating not stationary mode pile and may adversely affect the load-bearing characteristics of pile.

The use of thermal facilities in piles in cold climate can be considered reasonable and considered as a partial version of the needs of cold / heat building.

It is determined that the average amount of heat that can be obtained from single pile $-1,17 \mathrm{~kW} \cdot \mathrm{h}$. 


\section{References}

1. ASHRAE, Commercial [Text] / Institutional GroundSource Heat Pump Engineering Manual, American Society of Heating, Refrigerating, and Air-Conditioning Engineers, Inc. Atlanta. - GA, 2003.

2. Amis, T. Energy piles and other thermal foundations for GSHP [Text] / T. Amis, F. Loveridge // REHVA Journal. 2014. - P. 32-35. - Available at: http://www.rehva.eu/ fileadmin/REHVA_Journal/REHVA_Journal_2014/RJ_issue_ 1/P.32/32-35_Energy_piles_RJ1401_WEB.pdf

3. Design manual. Heat pumps [Text]. - Viessmann, 2012. - P. 65.

4. System using geothermal heat. Technical information [Text]. - REHAU, 2009. - P. 20.

5. Design manual. Heat pumps for heating and hot water supply [Text]. - Dimplex, 2009. - P. 77.

6. Suguang, X. Use of Geothermal Deep Foundations for Bridge Deicing [Text] / S. Xiao, M. Suleiman, C. Naito, S. Neti // Transportation Research Record: Journal of the Transportation Research Board. - 2013. - Vol. 2363. - P. 5665. doi: 10.3141/2363-07

7. Rees, S. A Study of Geothermal Heat Pump and Standing Well Perfomance [Text] / S. Rees, J. Splintler, Z. Deng, C. Orio, C. Johnson // ASHRAE. - 2004. - Vol. 109. - P. 3-13.

8. Xiao, S. Use of Geothermal Deep Foundations for Bridge Deicing, Lehigh University [Text] / S. Xiao, M. T. Suleiman, C. J. Naito, S. Neti. - Report of TRB 2013 Annual Meeting, 2013.

9. Man, Y. Development of spiral heat source model for novel pile ground heat exchangers [Text] / Y. Man, H. Yang, N. Diao, P. Cui, L. Lu, Z. Fang // HVAC\&R Research. - 2011. Vol. 17, Issue 6. - P. 1075-1088. doi: 10.1080/10789669. 2011.610281
10. Thermal Pile Design, Installation \& Materials Standards [Text]. - Milton, UK., 2012. - 85 p. - Available at: http://www.gshp.org.uk/pdf/GSHPA_Thermal_Pile_Standard.pdf

\section{References}

1. ASHRAE, Commercial (2003). GA.

2. Amis, T., Loveridge, F. (2014). Energy piles and other thermal foundations for GSHP. REHVA Journal, 32-35. Available at: http://www.rehva.eu/fileadmin/REHVA_Journal/ REHVA_Journal_2014/RJ_issue_1/P.32/32-35_Energy_piles_ RJ1401_WEB.pdf

3. Design manual. Heat pumps (2012). Viessmann, 65.

4. System using geothermal heat. Technical information (2009). REHAU, 20.

5. Design manual. Heat pumps for heating and hot water supply (2009). Dimplex, 77.

6. Xiao, S., Suleiman, M., Naito, C., Neti, S. (2013). Use of Geothermal Deep Foundations for Bridge Deicing. Transportation Research Record: Journal of the Transportation Research Board, 2363, 56-65. doi: 10.3141/2363-07

7. Rees, S., Splintler, J., Deng, Z., Orio, C., Johnson, C. (2004). A Study of Geothermal Heat Pump and Standing Well Perfomance. ASHRAE, 109, 3-13.

8. Xiao, S., Suleiman, M. T., Naito, C. J., Neti, S. (2013). Use of Geothermal Deep Foundations for Bridge Deicing, Lehigh University. Report of TRB 2013 Annual Meeting.

9. Man, Y., Yang, H., Diao, N., Cui, P., Lu, L., Fang, Z. (2011). Development of spiral heat source model for novel pile ground heat exchangers. HVAC\&R Research, 17 (6), 10751088. doi: 10.1080/10789669.2011.610281

10. Thermal Pile Design, Installation \& Materials Standards (2012). Milton, UK., 85. Available at: http://www.gshp. org.uk/pdf/GSHPA_Thermal_Pile_Standard.pdf

\section{Рекомендовано до публікації д-р техн. наук, професор Приймак О. В.} Дата надходження рукопису 08.06.2016

Kuzytskyi Ivan, Postgraduate student, Department of Heat Engineering, Kyiv National University of Construction and Architecture, Povitroflotskyi ave., 31, Kyiv, Ukraine, 03680

E-mail: Kuzytskyi@gmail.com

\section{УДК 004.8, 004.94}

DOI: $10.15587 / 2313-8416.2016 .73625$

\section{ЕФЕКТИВНА ПОБУДОВА ШЛЯХУ ДЛЯ ЧОТИРИКОЛІСНИХ РОБОТІВ НА ОСНОВІ ПОЄДНАННЯ АЛГОРИТМІВ Тheta* I ГІБРИДНОГО А*}

\section{(C) В. Г. Михалько, І. В. Круш}

Запропоновано алгоритм ефективної побудови шляху для чотириколісних роботів на основі поєднання алгоритмів Theta* $i$ гібридного $A^{*}$. Наведено і пояснено псевдокод для алгоритму . Реалізовано запропонований алгоритм і симулятор чотириколісного робота на мові програмування Јаvа. Протестовано роботу алгоритму для U-подібних перешкод, складних карт і для вирішення задачі паркування

Ключові слова: робототехніка, чотириколісні роботи, штучний інтелект, алгоритм пошуку шляху, Theta*, гібридний $A^{*}$

Effective pathfinding algorithm based on Theta* and Hybrid A* algorithms was developed for four-wheeled robot. Pseudocode for algorithm was showed and explained. Algorithm and simulator for four-wheeled robot were implemented using Java programming language. Algorithm was tested on U-obstacles, complex maps and for parking problem

Keywords: robotics, four-wheeled robot, artificial intelligence, pathfinding algorithm, Theta*, Hybrid A*

\section{1. Вступ}

Одним із основних напрямків у сучасній робототехніці є проектування і побудова безпілотних ав- томобілів. Зважаючи на значну кількість автомобільних аварій, які є наслідком людської помилки, а також на те, що системи, засновані на використанні 